\title{
TUMPANG TINDIH PENGELOLAAN TEMPAT PARKIR (Studi tentang Retribusi dan Pajak Parkir di Kota Malang)
}

\author{
Dewi Citra Larasati'; Abd. Rohman ${ }^{2}$ \\ ${ }^{1,2}$ Program Studi Administrasi Publik, Fakultas Ilmu Sosial dan Politik \\ Universitas Tribhuwana Tunggadewi \\ Email: citralarasati311@gmail.com; rohmanch93@yahoo.com
}

\begin{abstract}
Abstrak : Permasalahan parkir di Kota Malang sangatlah kompleks, terlebih ketika adanya kenaikan tarif parkir di tahun 2015, menyebabkan muncul masalah-masalah lain yang lebih pelik, seperti tumpang tindihnya pengelolaan pajak parkir dan retribusi, munculnya juru parkir ilegal sampai dengan premanisme. Latar belakang tersebut membuat peneliti melakukan penelitian dengan tujuan untuk menganalisis pengelolaan tempat parkir di Kota Malang. Peneliti menggunakan metode kualitatif dengan pendekatan yang holistik mampu menghasilkan data melalui teknik pengumpulan data menggunakan triangulasi. Dari kegiatan penelitian ini adalah adanya tumpang tindih pengelolaan tempat parkir antara pajak parkir dan retribusi parkir dikarenakan adanya dua perauran daerah yang mengatur keduanya dan belum ada perwal yang mengatur tentang pengelolaan parkir sehingga muncul konflik internal di Organisasi Perangkat Daerah (OPD) yang mengelola parkir maupun konflik eksternal (masyarakat), selain itu minimnya pengawasan dan pengendalian terhadap juru parkir ilegal yang ada di Kota Malang.
\end{abstract}

\section{Kata Kunci: Manajemen Parkir; Pajak; Retribusi}

Abstract : The problem of parking in Malang is very complex, especially when there is an increase in parking fees in 2015. this causes other more complicated problems, such as overlapping management of parking taxes and user fees, the emergence of illegal parking attendants to thuggery. This background makes researchers conduct research with the aim to analyze the management of parking lots in the city of Malang.Researchers use qualitative methods with a holistic approach that is able to obtain data with data collection techniques using triangulation. The results of this research are the overlapping parking management between parking taxes and parking fees due to the absence of guardians governing parking management so that internal conflicts arise in the Regional Apparatus (OPD) that manages parking and external conflicts (the public), besides the lack of supervision and control Illegal parking attendant in Malang city

Keywords: Parking Management; tax; Retribution

\section{PENDAHULUAN}

Penyerahan kewenangan pemerintah dari pusat ke daerah berasaskan otonomi daerah telah berjalan selama dua puluh satu tahun. Dalam perjalanannya tersebut, peraturan perundang-undangan telah berganti berulang kali. Berawal dari Undang - Undang nomor 22 tahun 1999 tentang Pemerintahan Daerah hingga saat ini Undang - Undang nomor 9 tahun 2015 tentang Perubahan Kedua atas Undang - Undang nomor 23 tahun 2014 tentang Pemerintahan Daerah adalah peraturan yang menjadi payung hukum otonomi daerah bagi pemerintah daerah dalam menyusun, mengatur, dan mengurus daerahnya di seluruh aspek secara mandiri tanpa adanya intervensi dari Pemerintah Pusat. Otonomi daerah telah banyak membawa implikasi positif terhadap daerah - daerah untuk lebih mandiri dan mengetahui segala hal yang dibutuhkan oleh daerahnya dan semakin mudah untuk melakukan pemeratan pembangunan di seluruh wilayah Indonesia. Dalam upaya menjalankan otonomi daerah, Pemerintah Daerah mempunyai hak dan kewajiban mengatur dan mengurus sendiri urusan pemerintahannya untuk meningkatkan efisiensi dan efektifitas penyelenggaraan pemerintahan dan pelayanan kepada masyarakat. Salah satunya dengan cara 


\section{REFORMASI}

ISSN 2088-7469 (Paper) ISSN 2407-6864 (Online)

Volume 10 Nomor 1 (2020)

mengenakan pungutan terhadap masyarakatnya. Hal ini sebagaimana diatur dalam Undang - Undang Nomor 28 tahun 2009 tentang Pajak Daerah dan Retribusi Daerah yang bertujuan agar Pemerintah Daerah mempunyai kewenangan untuk melakukan pemungutan Pajak Daerah dan Retribusi Daerah (PDRD) kepada masyarakat, yang mana hasil dari pemungutan PDRD tersebut akan digunakan untuk membiayai pembangunan dalam rangka memberikan pelayanan kepada masyarakat.

PDRD yang dipungut dari masyarakat, diharapkan pengelolaannya dapat memberikan kesejahteraan dan manfaat yang besar bagi seluruh lapisan masyarakat. Karena indikator keberhasilan otonomi daerah adalah jika daerah mampu membiayai penyelenggaraan pembangunan dan pelayanan kepada masyarakat. Dimana penyelenggaraan dan pelayanan oleh pemerintah daerah sangat erat kaitannya dengan beberapa urusan pemerintahan wajib yang berkaitan dengan pelayanan dasar dan urusan pemerintahan wajib yang tidak berkaitan dengan pelayanan dasar. Salah satu dari urusan pemerintahan wajib yang berkaitan dengan pelayanan dasar tersebut adalah ketentraman dan ketertiban umum juga perlindungan masyarakat.

Kota Malang merupakan salah satu kota terbesar kedua di Provinsi Jawa Timur setelah Kota Surabaya. Kota Malang mempunyai cita-cita yang tercantum dalam semboyan Tri Bina Cita, yaitu Kota Malang sebagai Kota Pendidikan, Kota Wisata, dan Kota Industr. Menyandang tiga identitas tersebut bukanlah hal yang mudah, apalagi mendapat sebutan sebagai Kota Pendidikan di Jawa Timur, hal ini dikarenakan di Malang banyak terdapat sekolah maupun perguruan tinggi yang ada di Kota Malang. Implikasi dari keadaan tersebut salah satunya adalah masuknya penduduk pendatang ke Kota Malang. Sehingga mobilitas dan volume kendaraan semakin meningkat dengan begitu pesat. Seiring dengan kepadatan tersebut, maka semakin meningkat pula kebutuhan parkir oleh masyarakat yang ada di Kota Malang, baik itu penduduk asli Kota Malang ataupun penduduk pendatang. Dengan keadaan yang demikian seharusnya hasil dari pengelolaan parkir di Kota Malang bisa membawa dampak positif yaitu meningkatnya Pendapatan Asli Daerah (PAD).

Ironisnya harapan tersebut sampai dengan saat ini tidak sesuai ekspektasi, teori tidak selalu berjalan mulus dengan praktek. Pengelolaan tempat parkir yang diharapkan mampu memberikan pelayanan terbaik pada masyarakat terutama ikut berperan aktif dalam menyumbang PAD kepada Pemkot Malang ternyata malah menimbulkan permasalah yang sangat kronis. Hal ini dikarenakan terjadinya tumpang tindih pengelolaan antara pajak parkir dan retribusi parkir, beberapa inovasi mengenai pengelolaan parkir yang pernah dirancangpun tak kunjung terealisasi. Permasalahan tersebut dapat dilihat mulai dari sisi pengambil kebijakan sampai dengan sisi pelaksaan yang terjadi di lapangan. Seperti beberapa permasalahan yang bisa peneliti contohkan yaitu adanya ketidakjelasan penetapan zona parkir, penggunaan fasum sebagai lokasi parkir, bermunculannya juru parkir ilegal, dan premanisme. Bahkan terjadinya tawuran antara dua kelompok masyarakat di kompleks rumah toko (ruko) WOW Sawojajar di tahun 2012 hingga menelan korban satu nyawa yang sampai sekarang pun sengketa parkir di lokasi tersebut belum terselesaikan. Pemicunya adalah kepemilikan sengketa lahan parkir antara LPMK (Lembaga Pemberdayaan Masyarakat Kelurahan) Sawojajar dengan warga kelurahan yang bernama Budi Santoso. Permasalahan diakibatkan karena adanya Nomor Pokok Wajib Pajak Daerah (NPWPD) ganda. Awalnya milik LPMK Sawojajar, kemudian muncul yang baru milik Budi Santoso (Satukanal.com, 28/11/2019).

Permasalahan parkir lainnya muncul di tahun 2015 yaitu adanya kenaikan tarif retribusi parkir yang akhirnya menimbulkan permasalahan baru yaitu menjamurnya keberadaan juru parkir (jukir) liar. Adanya tindakan jukir liar yang mencoreng nama Kota Malang sehingga membuat nitizen membuat petisi "Malang Darurat Parkir" di tahun 2016. Kejadian ini dipicu oleh adanya aksi premanisme dari jukir liar yang menyebabkan masyarakat Kota Malang merasa sangat keberatan dengan adanya kenaikan tarif tersebut dan merasa kecewa dengan tindakan dan perilaku jukir liar dalam mengelola tempat parkir yang 


\section{REFORMASI}

ISSN 2088-7469 (Paper) ISSN 2407-6864 (Online)

Volume 10 Nomor 1 (2020)

tidak berdasarkan prosedur. Termasuk adanya jukir yang menarik tarif parkir bus pariwisata di Alun Alun Kota Malang sebesar Rp 50.000, padahal penerapan tarif parkir di Kota Malang sudah diatur dalam Perda Kota Malang Nomor 3 tahun 2015 tentang Retribusi Jasa Umum bahwa retribusi parkir di tepi jalan umum untuk bus besar adalah Rp 10.000 dan minibus atau sejenisnya sebesar Rp 5.000 (surabaya.tribunnews.com, 17/6/2019).

Berdasarkan permasalahan pengelolaan parkir yang muncul di Kota Malang, membuat melatarbelakangi peneliti untuk melakukan penelitian yang mana tujuannya adalah untuk mengetahui dan menganalisis tumpang tindihnya pengelolaan parkir di Kota Malang. Untuk mendukung penelitian ini, maka ada beberapa teori yang peneliti gunakan untuk menunjang analisis antara lain fungsi manajemen, pengendalian dan pengawasan, prinsip pelayanan publik, dan hambatan dalam penerapan fungsi manajemen. Fungsi manajemen yang dianggap mewakili dalam pengelolaan tempat parkir adalah fungsi manajemen menurut Urwick dalam Rohman (2018, 26-27) menjelaskan bahwa fungsi-fungsi menajemen adalah sebagai berikut forecasting, planning, organizing, commanding, cordinating, controlling. Dari banyak fungsi manajemen tersebut maka salah satu fungsi manajemen yang sangat berkaitan dengan pengelolaan parkir di Kota Malang adalah pengendalian atau pengawasan. Di dalam buku yang sama, Wijayanti dalam Rohman (2018:187-189) menjelaskan bahwa pengendalian dan pengawasan adalah kegiatan untuk memastikan bahwa pekerjaan - pekerjaan di lapangan telah sesuai dengan perencanaan dan mencapai hasil yang dikehendaki, sehingga pengendalian dan pengawasan memiliki peran penting dalam pencapaian tujuan sesuai dengan rencana yang telah ditetapkan. Empat langkah yang harus dilaksanakan dalam pengendalian dan pengawasan adalah 1) Penentuan standart, 2) Pengukuran performance dilakukan dengan observasi atau pengamatan, wawancara, dan 3) Menelaah laporan-laporan tertulis tentang hasil yang dicapai, termasuk ketika terjadi penyimpangan.

Dalam pelayanan publik juga harus ada standar pelayanan yang mana standar tersebut harus memenuhi prinsip pelayanan publik menurut Mukarom dan Muhibudin (2015:116-117) sebagaimana berikut ini : a. Kesederhanaan (dimana prosedur pelayanan tidak boleh berbelit-belit) b. Kejelasan (berhubungan dengan persyaratan teknis dan pelayanan administrasi, penanggungjawab dalam pelayanan, rincian serta tata cara pembayaran) c. Kepastian waktu (diselesaikan dengan cepat) d. Akurasi (diterima dengan benar, tepat dan sah) e. Keamanan (bisa memberikan rasa aman dan kepastian hukum) f. Tanggung jawab (pengelola bertanggung jawab atas penyelenggaraan pelayanan dan menyelesaikan keluhan yang ada) g. Kelengkapan sarana dan prasarana h. Kemudahan akses i. Kedisiplinan, kesopanan serta keramahan pemberi layanan, dan j. Kenyamanan konsumen.

Hambatan dalam penerapan fungsi manajemen secara umum dapat dibagi dalam dua golongan yaitu : 1) Hambatan Internal maupun 2) Hambatan Eksternal. Hambatan internal ini meliputi a) manajer belum memahami aspek yang berkaitan dengan fungsi-fungsi manajemen, b) manajer seringkali masih kurang mampu menjabarkan fungsi-fungsi manajemen secara operasional, c) organisasi belum siap melaksanakan fungsi-fungsi manajemen yang digariskan oleh manajer, d) belum tersedianya sarana dan prasarana, e) adanya faktor resiko dan ketidakpastian, sedangkan Hambatan eksternal meliputi : a) adanya berbagai peraturan, ketentuan, dan perundang-undangan pemerintah, b)adanya dampak negatif dari pengembangan organisasi, c) tidak mendukungnya infrastruktur di luar organisasi. (Rohman, 2018:67$68)$.

Selain beberapa hambatan yang telah disebutkan diatas, Rohman dan Willy (2019: 29-30) juga menjelaskan mengenai permasalahan yang dihadapi oleh birokrasi saat ini yaitu : 1) Masalah organisasi, organisasi yang ada belum tepat fungsi dan tepat ukuran, 2) Masalah peraturan, adanya tumpang tindih, inkonsistensi, tidak jelas dan multitafsir. Serta beberapa peraturan tidak disesuaikan dengan dinamika perubahan penyelenggaraan pemerintah dan tuntutan masyarakat. 3) Masalah SDM Aparatur, 4) Masalah kewenangan, dimana masih adanya praktik penyimpangan dan penyalahgunaan kewenangan serta belum 


\section{REFORMASI}

ISSN 2088-7469 (Paper) ISSN 2407-6864 (Online)

Volume 10 Nomor 1 (2020)

mantapnya akuntabilitas kinerja instansi pemerintah, 5) Masalah pelayanan publik, belum mengakomodasi kepentingan seluruh lapisan masyarakat, karena belum memenuhi hak dan harapan warga. 6) Masalah pola pikir (mindset) dan budaya kerja (culture set).

\section{METODE PENELITIAN}

Peneliti menggunakan sebuah pendekatan yang holistik dalam memperoleh data mengenai pengelolaan parkir di Kota Malang, dengan begitu peneliti mengharapkan akan mendapatkan data secara objektif. Sehingga metode penelitian kualitatif dianggap cocok dalam penelitian ini. Dalam mengumpulkan data, peneliti menggunakan teknik triangulasi menggabungkan teknik observasi moderat dan wawancara tidak terstruktur, serta menggunakan beberapa data-data arsip kantor sebagai dokumentasi penelitian. Bila melihat dari sumber datanya maka penelitian ini menggunakan sumber primer dan sekunder (Sugiyono, 2018:308). Sumber primer adalah sumber data yang langsung memberikan data pada pengumpul data, sedangkan sumber sekunder merupakan sumber yang tidak langsung memberikan data pada pengumpul data. Penelitian ini dengan disertai pengecekan keabsahan data hasil penelitian menggunakan triangulasi sumber dan teknik. Analisis yang digunakan oleh peneliti adalah menggunakan analisis interaktif. Dimana analisis dilakukan secara terus menerus sampai fokus yang dicari didapatkan secara tuntas, sehingga datanya jenuh (model Miles and Huberman).

\section{HASIL DAN PEMBAHASAN}

\section{Pengelolaan Tempat Parkir di Kota Malang}

Pengaturan pengelolaan tempat parkir pada dasarnya memiliki beberapa tujuan yaitu 1) mengatur kendaraan yang sedang parkir dengan mempertimbangkan dampak - dampak yang ditimbulkan, 2) menjamin keteraturan lingkungan, ketertiban lingkungan, dan kenyamanan lingkungan ketika suatu tempat dijadikan sebagai lahan parkir, 3) mengantisipasi dan meminimalisasi tindak pidana kejahatan pada kendaraan yang sedang parkir dan 4) memberikan jaminan perlindungan kepada masyarakat yang memarkir kendaraannya. Pengelolaan tempat parkir di Kota Malang diatur dalam Peraturan Daerah Nomor 4 Tahun 2009 tentang Pengelolaan Tempat Parkir. Dalam peraturan tersebut dijelaskan bahwa ruang lingkup pengaturan terhadap Pengelolaan Tempat Parkir seperti tempat parkir yang berada di mall mall, tempat parkir yang disediakan di pertokoan, tempat parkir di tepi jalan raya, sampai dengan tempat tempat parkir lainnya yang ada di perkantoran baik yang dikelola oleh pemerintah daerah maupun swasta.

Berdasarkan ruang lingkupnya yang telah dijelaskan di atas, tempat parkir kendaraan dikelompokkan ke dalam beberapa jenis-jenis tempat parkir yaitu : 1) Tempat parkir umum, adalah tempat parkir yang berada di tepi jalan atau halaman perkantoran ataupun pertokoan yang tidak bertentangan dengan rambu-rambu lalu lintas dan tempat lain sejenisnya yang diperbolehkan untuk tempat parkir umum, 2) Tempat parkir khusus, adalah tempat parkir yang secara khusus dikelola, disediakan, dan dimiliki oleh Pemkot Kota Malang meliputi pelataran/lingkungan parkir, taman parkir, gedung parkir dan sejenisnya. 3) Tempat parkir kegiatan insidentil, adalah tempat parkir kendaraan yang diselenggarakan suatu kepentingan atau kegiatan/keramaian secara tidak tetap/tidak permanen, dan 4) Tempat khusus parkir, adalah tempat parkir yang dimiliki oleh orang atau badan pada usaha pokoknya menyediakan fasilitas parkir yang memiliki surat ijin usaha sesuai dengan ketentuan peraturan perundang-undangan.

Selain pengelompokan tersebut dalam Perda Nomor 4 Tahun 2009 juga dijelaskan mengenai pengelolaan parkir kendaraan di Kota Malang diklasifikan menjadi retribusi dan pajak. Ada perbedaan yang signifikan dalam pemaknaan retribusi dan pajak. Retribusi Parkir disini diartikan sebagai semua lahan parkir yang ada di daerah, dan lahan ini dikuasai serta dikelola oleh Pemerintah Daerah dalam hal ini adalah Pemerintah Kota (Pemkot) Malang. Sedangkan Pajak Parkir adalah lahan parkir yang dimiliki 


\section{REFORMASI}

ISSN 2088-7469 (Paper) ISSN 2407-6864 (Online)

Volume 10 Nomor 1 (2020)

dan dikelola oleh badan atau perseorangan yang memiliki ijin usaha perparkiran. Sehingga dapat dibuatkan bagan pengklasifikasian sebagaimana berikut :

Gambar 1 Pengklasifikasian Pengelolaan Tempat Parkir Di Kota Malang

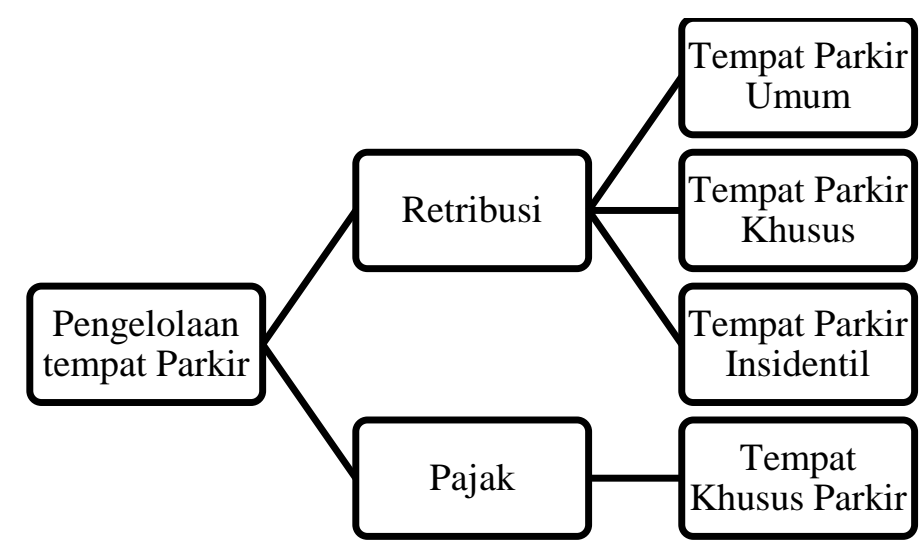

Sumber : Analisis Data Penelitian, Maret 2020

\section{A. Retribusi Parkir}

Penanggung jawab pengelolaan tempat parkir untuk retribusi parkir adalah Dinas Perhubungan (Dishub) Kota Malang. Dishub Kota Malang melakukan pengelolaan tempat parkir sebagaimana berikut :

1. Melakukan pendataan terhadap titik parkir atau lokasi parkir dan mendata juru parkir (jukir) yang menarik/memungut retribusi parkir di titik atau lokasi tersebut.

2. Jukir wajib menggunakan atribut parkir resmi, seperti: rompi yang telah terdaftar dan Kartu Tanda Anggota Jukir (Petugas parkir) . serta telah dibekali surat tugas penunjukan sebagai petugas parkir

3. Jukir telah melakukan tugas dan kewajibannya dengan melakukan pemungutan retribusi kepada konsumen pengguna jasa retribusi dengan tarif sesuai yang tertera resmi pada karcis yang telah disediakan.

4. Melakukan pengawasan terhadap lokasi titik-titik parkir yang tersebar di seluruh wilayah Kota Malang. Pengawasan dilakukan dengan melibatkan semua stakeholders yang ada. Seperti Sattpol PP sebagai polisi Perda di daerah, POLRI dan masyarakat Kota Malang.

Retribusi Parkir yang dikelola oleh Dishub adalah Retribusi Jasa Umum dan Retribusi Jasa Usaha. Retribusi Jasa Umum ini meliputi pengelolaan tempat parkir di tepi jalan raya. Tempat parkir di tepi jalan raya ditandai dengan adanya garis batas parkir yang ada pada lahan parkir di tepi jalan raya, dimana untuk kendaraan roda empat dibuat dengan kemiringan garis batas sebesar 15 derajat sedangkan untuk kendaraan roda dua cukup dengan tanda batas lahan parkir. Namun masih banyak tempat parkir di tepi jalan raya yang tidak sesuai dengan aturan tersebut. Hal ini juga dikarenakan regulasi secara detail mengenai pengaturan penetapan tempat parkir (titik parkir) belum ada Peraturan Walikotanya, sehingga terdapat ketidakjelasan mengenai persyaratan dan tata cara pengaturannya. Selama ini berdasarkan penuturan beberapa informan, kebiasaan yang berlaku di Dishub, jika ada orang yang hendak melakukan pengurusan permohonan izin lokasi untuk pengelolaan tempat parkir umum, maka dari itulah ada beberapa hal persyaratan yang harus dipenuhi, diantaranya adalah :

1. Pengaturan Perizinan meliputi :

a. Tidak adanya pelanggaran aturan lalu lintas,

b. Tidak sampai mengganggu kepentingan umum, 


\section{REFORMASI}

ISSN 2088-7469 (Paper) ISSN 2407-6864 (Online)

Volume 10 Nomor 1 (2020)

c. Ada keterngan yang memberikan izin menyatakan bahwa pemilik tidak keberatan akan tempat parkir yang akan dikelola dengan didukung keterangan dari wilayah setempat yaitu RT/RW.

2. Syarat bagi calon pengelola tempat parkir :

a. Mengajukan permohonan yang ditujukan kepada Dinas Perhubungan dengan memenuhi point (1) dengan melampirkan Surat Ijin atau Surat Pernyataan Pemilik Lokasi

b. Membuat surat pernyataan bahwasanya akan mentaati semua ketentuan/peraturan yang dikeluarkan oleh Pemkot Malang,

c. Menyerahkan foto copy KK \& KTP

d. Materai Rp 6.000,- sebanyak 2 lembar

e. Foto dengan background merah $4 \times 6$ dengan jumlah 4 lembar

f. Seluruh berkas dimasukkan ke dalam map biru (untuk perpanjangan Surat Penunjukan Jukir) dan map hijau (untuk titik parkir baru)

g. Selanjutnya akan dibuatkan Surat Penunjukan bila sudah dilakukan survey lokasi

h. Dibuatkan surat perjanjian besaran jumlah nominal untuk target setoran.

i. Pemberian surat tugas penunjukan sebagai jukir dan Kartu Tanda Anggota dan rompi dan karcis parkir.

Prosedur pemungutan retribusi parkir di Kota Malang diawali dengan: a. Pencetakan sejumlah karcis oleh Dishub, kemudian karcis dibuat rangkap dua serta diberi seri/urut (diperforasi) untuk memudahkan pengawasan dan pengendalian termasuk menyusun laporan untuk dijadikan arsip bagi Dinas Perhubungan. b. Karcis didistribusikan kepada koordinator parkir atau jukir untuk memungut retribusi parkir kepada konsumen pengguna layanan jasa parkir. c. Karcis yang dibawa jukir dan hasil pemungutan retribusi disetorkan kepada koordinator atau langsung kepada petugas Dinas Perhubungan yang telah ditunjuk. d. Juru parkir atau koordinator diberi kuitansi sebagai tanda bukti penyetoran dari Dishub.

Untuk pengenaan tarif Retribusi Jasa Umum ini mengacu pada Perda Nomor 3 Tahun 2015 tentang Retribusi Jasa Umum, dimana tarif parkir tepi jalan raya ditetapkan berdasarkan jenis kendaraan bermotor yang ada sebagaimana berikut :

1. Truk Gandeng, Truk Trailler dan bus besar sebesar Rp. 10.000,-

2. Truk dan minibus dan sejenisnya sebesar Rp. 5.000,-

3. Mobil sedan, Jeep, Pick Up dan sejenisnya sebesar Rp. 3.000,-

4. Sepeda Motor sebesar Rp. 2.000,-

Sedangkan untuk besaran tarif retribusi parkir insidentil tepi jalan raya ditetapkan sebagai berikut :

1. Truk, bus dan minibus dan sejenisnya sebesar Rp. 20.000,-

2. Mobil sedan, Jeep, Pick Up dan sejenisnya sebesar Rp. 5.000,-

3. Sepeda Motor sebesar Rp. 3.000,-

Retribusi jasa usaha biasanya diberlakukan untuk tempat parkir di perkantoran ataupun beberapa aset yang dimiliki oleh Pemerintah Daerah. Berdasarkan Peraturan Daerah Nomor 2 Tahun 2011 tentang Retribusi Jasa Usaha, dijelaskan dalam perda tersebut bahwa Tempat Parkir Khusus adalah tempat yang secara khusus disediakan, dimiliki kemudian dikelola oleh Pemerintah Daerah. Dimana meliputi pelataran/lingkungan parkir, taman parkir dan/atau gedung parkir dan sejenisnya. Seperti : Parkir depan Stadion Gajayana, Parkir Gedung Kartini, Parkir di Pelataran Kantor Gedung Terpadu (Block Office), dan lain-lain. Sedangkan untuk besaran tarif yang berlaku bagi retribusi jasa usaha ditetapkan berdasarkan jenis kendaraan bermotor, sebagaimana berikut :

1. Truk, Bus, minibus dan sejenisnya sebesar Rp. 4.000,- 


\section{REFORMASI}

ISSN 2088-7469 (Paper) ISSN 2407-6864 (Online)

Volume 10 Nomor 1 (2020)

2. Mobil sedan, Jeep, Pick Up dan sejenisnya sebesar Rp. 2.000,-

3. Sepeda Motor sebesar Rp. 1.000,-

Sedangkan untuk tarif Retribusi Tempat Khusus Parkir yang sifatnya insidentil ditetapkan sebagaimana berikut :

1. Bus, Truk dan sejenisnya sebesar Rp. 10.000,-

2. Mobil sedan, Jeep, Pick Up dan sejenisnya sebesar Rp. 3.000,-

3. Sepeda Motor sebesar Rp. 2.000,-

Penggunaan fasilitas Tempat Parkir Umum dan Tempat Parkir Khusus dikenakan tarif retribusi yang besarannya diatur seperti yang telah peneliti jelaskan. Permasalahannya selama ini, banyak masyarakat yang kurang paham, bahkan tidak mengetahui mengenai adanya perbedaan tarif yang ada. Sama - sama retribusinya namun terdapat perbedaan tarif karena terdapat dua regulasi yang mengatur, sehingga adanya perbedaan tarif tempat parkir umum dan tempat parkir khusus. Beberapa masyarakat dan pengamat di media sering mengkritisi mengenai karcis parkir yang ada di Kota Malang. Keluhan masyarakat yang dimuat dalam berita online malangtimes menjelaskan mengenai karcis parkir yang dibagikan ketika ada acara pergelaran HUT Korpri di Balai Kota. Karcis parkir yang diberikan masih tertera peraturan daerah (perda) serta tarif parkir lama, yaitu jenis parkir khusus yang seharusnya parkir insendentil, perda lama Nomor 1 tahun 2011 yang seharusnya perda terbaru yang Nomor 3 tahun 2015, lalu tarif parkir lama Rp 2.000 yang seharusnya Rp 3.000 (malangtimes.com, 29/11/2015)

Dari permasalahan kerancuan karcis tersebut sebenarnya bisa dianalisis sebagaimana berikut:

1) Pemkot Malang sedang mengadakan acara peringatan HUT Korpri di Balaikota ini menandakan kantor sedang ada kegiatan / acara, kegiatan / acara ini termasuk dalam kegiatan insidentil,

2) Lokasi parkir adalah di area Balai Kota Malang sehingga berdasarkan lokasinya termasuk dalam

Retribusi Jasa Usaha dimana tarif yang melekat untuk pemungutan tarif adalah menggunakan Perda nomor 2 tahun 2011 tentang retribusi jasa usaha dimana tarif insidentil parkir untuk Mobil dan sejenisnya sebesar Rp. 3.000,-

Sehingga karcis parkir yang diterimakan kepada masyarakat tersebut sudah sesuai dengan peraturan yang berlaku. Kebingungan dan kerancuan antara retribusi jasa umum dengan retribusi jasa usaha serta sosialisasi yang kurang menyentuh masyarakat menyebabkan terjadinya disinformasi. Berikut adalah skema yang bisa dibuat mengenai pengelolaan parkir retribusi :

Gambar 2. Skema Retribusi Parkir

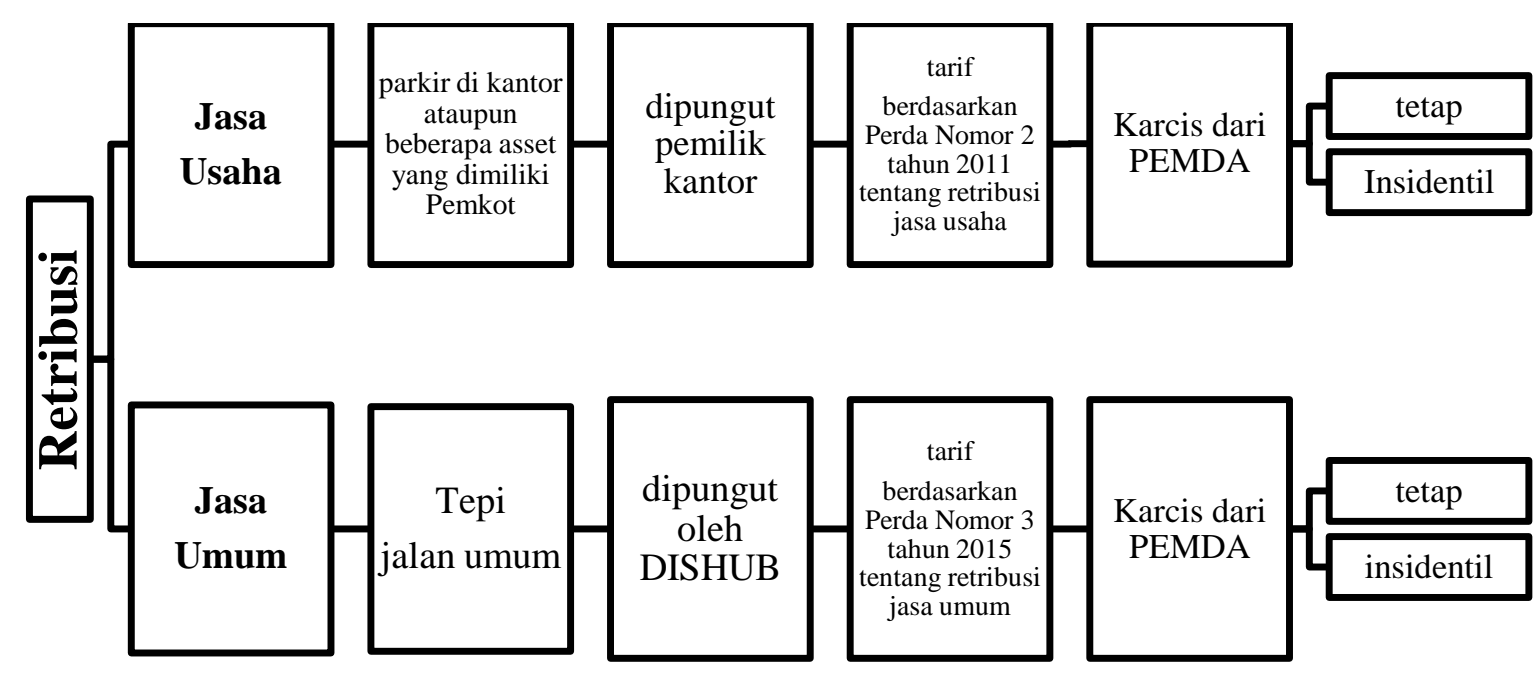

Sumber : Analisis Data Penelitian, Maret 2020 


\section{REFORMASI}

ISSN 2088-7469 (Paper) ISSN 2407-6864 (Online)

Volume 10 Nomor 1 (2020)

Pengawasan yang telah dilakukan oleh Dishub dalam memantau beberapa titik parkir di Kota Malang adalah dengan beberapa cara berikut ini : Pertama, Mengadakan pengecekan secara langsung ke beberapa area titik parkir yang ada di Kota Malang. Karena terbatasnya jumlah pegawai / Sumber Daya Manusia (SDM) pada bidang perparkiran, maka pengawasan dilakukan bertahap sesuai jadwal yang telah ditentukan. Pengawasan yang dilakukan diantaranya terkait kelengkapan juru parkir. Kedua, Melakukan pengawasan secara khusus. Pengawasan secara khusus adalah pengawasan yang dilakukan karena menindaklanjuti laporan pelanggaran yang disampaikan oleh masyarakat atau berasal dari laporan petugas Dinas Perhubungan sendiri bisa melalui aplikasi sambat online atau melalui sms/WA. Ketiga, melakukan kegiatan evaluasi kerja. Setelah melakukan kegiatan pengawasan, baik pengawasan secara langsung maupun pengawasan khusus, kegiatan selanjutnya adalah evaluasi bersama yang dilakukan oleh pegawai Dishub yang bertugas di bidang perparkiran. Evaluasi dilakukan setiap bulan untuk membahas hasil pengawasan dan bagaimana solusi yang harus diambil untuk langkah selanjutnya.

Pengawasan dan evaluasi sudah sering kali dilakukan oleh Dishub dalam pengelolaan tempat parkir, namun ternyata masih banyak permasalahan yang timbul di lapangan. Salah satunya adalah permasalahan karcis parkir. Berdasarkan peraturan yang ada, telah diatur secara jelas bahwa pembayaran yang dilakukan oleh masyarakat terhadap retribusi pelayanan jasa parkir umum dan jasa parkir khusus diberikan bukti pembayaran berupa karcis parkir (Pasal 17 Ayat (1) Perda Kota Malang Nomor 4 Tahun 2009). Berikut ini adalah beberapa bentuk karcis retribusi parkir yang beredar di Kota Malang :

Gambar 3. Karcis Retribusi Parkir yang beredar di Kota Malang

\subsection{Karcis Retribusi Jasa Parkir Umum}

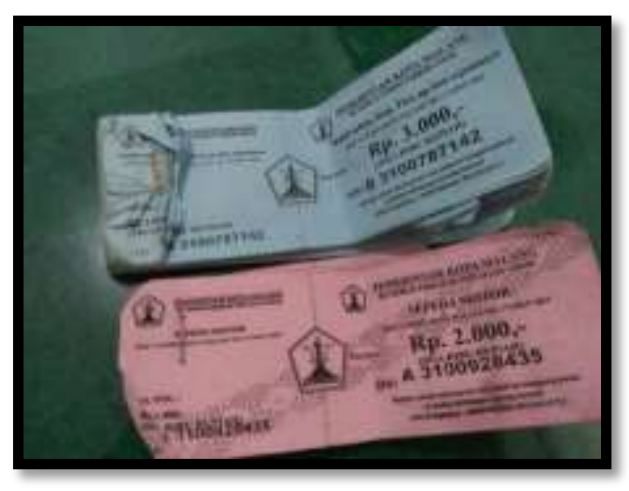

3.2 Karcis Retribusi Jasa Parkir Khusus

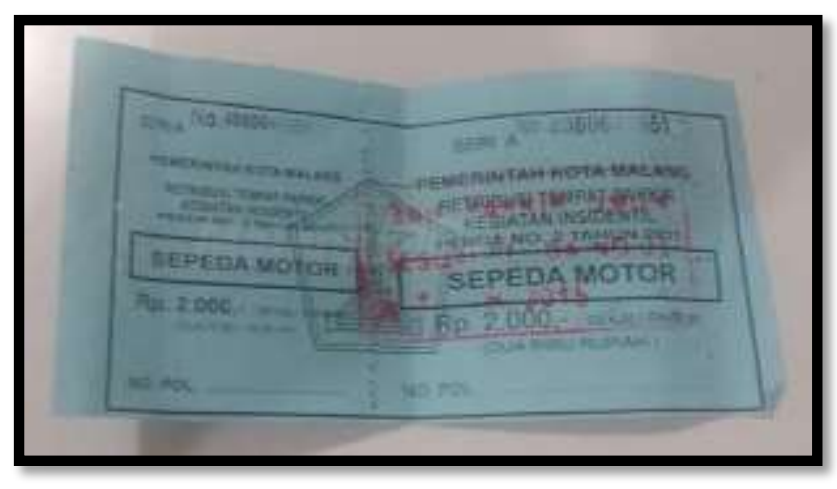

Sumber : Dokumentasi Penelitian, Maret 2020

Kurangnya sosialisasi serta budaya literasi yang rendah di kalangan masyarakat kota Malang mengenai pentingnya karcis parkir serta sikap acuh yang menyebabkan masih rendahnya pemahaman masyarakat terkait retribusi jasa umum dan retribusi jasa usaha. Seharusnya sebagai konsumen pengguna jasa parkir, meminta haknya untuk diberikan karcis parkir. Hal ini semakin diperparah dengan kesadaran jukir untuk memberikan hak masyarakat pengguna layanan berupa karcis parkir juga ditengarai banyak faktor antara lain : 1) Mereka adalah jukir ilegal yang tidak terdaftar (tidak memiliki surat penugasan, KTA dan rompi resmi), 2) Para jukir tidak memberikan karcis tersebut, 3) Sikap tidak ramah jukir ketika ada pengunjung yang meminta karcis parkir. 4) Karcis parkir yang digunakan lagi sampai berulang kali, 5) Beberapa pengguna jasa parkir bersikap abai dalam memperjuangkan haknya, sebagian dari mereka lebih memilih berdiam dikarenakan belum tentu jukir punya karcis atau karcis yg awalnya sudah diberikan diminta lagi oleh jukir. Padahal karcis ini merupakan tanda bukti pembayaran yang sah bahwa pengguna jasa parkir telah menggunakan jasa parkir, melalui karcis ini pulalah bisa dijadikan sebagai tanda bukti apabila ada kehilangan pada kendaraan yang diparkir, maka si pemilik kendaraan mempunyai 


\section{REFORMASI}

ISSN 2088-7469 (Paper) ISSN 2407-6864 (Online)

Volume 10 Nomor 1 (2020)

hak untuk meminta ganti rugi kepada petugas parkir. Karena sebagaimana telah diatur dalam Perda Nomor 4 Tahun 2009 Pasal 19 ayat (2) menyebutkan bahwa setiap petugas parkir yang karena kesengajaan sehingga menyebabkan hilangnya kendaraan yang diparkir dapat dituntut secara pidana.

\section{B. Pajak Parkir}

Apabila retribusi parkir dikelola oleh Dishub, maka pengelolaan pajak parkir sepenuhnya menjadi tanggung jawab dari Badan Pendapatan Daerah (Bapenda) Kota Malang. Pajak parkir adalah pajak atas penyelenggaraan tempat parkir di luar badan jalan, baik yang disediakan berkaitan dengan pokok usaha maupun yang disediakan sebagai suatu usaha, termasuk penyediaan tempat penitipan kendaraan bermotor. Usaha Pajak Parkir ini dimiliki oleh perorangan atau lahan milik pribadi dan badan usaha (pihak ketiga). Bagi perorangan atau badan usaha yang ingin memiliki usaha parkir maka perlu untuk mengurus izin usaha parkir. Jika tempat parkir yang akan dikelola tersebut hanya untuk usahanya sendiri maka perlu mengurus izin usaha perparkiran. Seperti : Indomaret, Swalayan Sardo, tempat penitipan sepeda dalam jangka waktu lama (menginap harian). Akan tetapi, jika usahanya telah bergabung dengan usaha yang lain, maka tidak perlu mengurus izin usaha perparkiran, dikarenakan sudah menyatu dengan amdal lalin bangunan tempat usaha bersama tersebut. Contoh : Malang Town Square (MATOS), Malang Olimpic Garden (MOG), Plaza Araya, Malang City Point (MCP) Malang Dinoyo Center (MDC), Plaza Dieng, beberapa hotel yang tersebar di Kota Malang, dan lain-lain.

Perda Nomor 16 tahun 2010 tentang Pajak Daerah menjelaskan bahwa Wajib Pajak (WP) dalam hal ini adalah pelaku usaha parkir. WP Parkir wajib mendaftarkan diri untuk mendapatkan NPWPD (Nomor Pokok Wajib Pajak Daerah), NPWPD diperoleh dengan dua cara yaitu dengan pelaporan dan pendataan. Berikut ini adalah syarat untuk mendapatkan NPWPD melalui sebagai berikut : mempersiapkan beeberapa berkas 1) Fotokopi KTP atau identitas lainnya sebagai penanggungjawab, 2) Fotokopi izin usaha. Mendapatkan NPWPD dengan mekanisme pelaporan, berati WP melaporkan secara aktif, namun jika NPWPD didapatkan melalui pendataan maka petugas aktif mendata WP tersebut. Dengan memiliki NPWPD maka WP memiliki kewajiban untuk melaporkan usahanya jika tidak ingin mendapatkan sanksi.

Pengenaan tarif pajak parkir adalah sebesar 20\% dari omset yang diperoleh oleh penyedia usaha perparkiran, namun tarif tersebut mengalami kenaikan menjadi 25\% berdasarkan Perda Nomor 8 tahun 2019 tentang Perubahan Kedua atas Perda Nomor 16 tahun 2010 tentang Pajak Daerah. Dalam hal ini, pengelola usaha parkir dapat menentukan tarif sendiri atau menggratiskan parkir sebagai bentuk pelayanan kepada pelanggan, asalkan kewajiban penyedia layanan usaha untuk membayar pajak parkir terpenuhi. Bapenda juga tidak pernah mempermasalahkan bagaimana pengelolaannya selama tidak menyalahi aturan. Bahkan untuk desain karcispun, penyedia layanan usaha perparkiran dipersilahkan asalkan karcis tersebut harus diperforasi dulu ke Bapenda.

Jangka waktu pajak parkir adalah selama 1 bulan. Sehingga wajib pajak dalam hal ini pengelola usaha perparkiran dapat melakukan membayar dengan menggunakan dua pilihan yaitu : Pertama, pajak dibayar oleh Wajib Pajak (WP) dengan terlebih dahulu ditetapkan oleh Bapenda dengan tarif flat dan disampaikan kepada WP setiap bulannya, kemudian WP membayarkan ke Bank Jatim. Mekanisme ini disebut denga Office Assessment (OA). Kedua, pajak yang dibayar WP dibayarkan sendiri dengan menghitung dan melaporkan sendiri pajak terutang menggunakan SPTPD (Surat Pemberitahuan Pajak Daerah). Mekanisme pelaporan ini biasa dikenal dengan Self Assesment (SA). Pelaporan tersebut dapat dilakukan dengan sistem manual (datang langsung ke kantor) ataupun dengan sistem daring. Sistem daring ini dilaksanakan menggunakan alat atau perekam data transaksi secara real time yang tersambung secara terintegrasi. Biasanya usaha perpakiran yang sudah menggunakan secure otomatis bisa kita lihat di beberapa pusat perbelanjaan di Kota Malang, seperti : di Matos, MOG, Plaza Araya, Malang Dinoyo 


\section{REFORMASI}

ISSN 2088-7469 (Paper) ISSN 2407-6864 (Online)

Volume 10 Nomor 1 (2020)

Center, dan Dieng Plaza. Namun bagi yang belum menggunakan sistem secure bisa melaporkan melalui aplikasi WhatsApp SMS, email, telpon, dan lain - lain. Apabila WP terlambat dalam melakukan pelaporan pajak bulanannya melebihi tanggal 10 bulan berikutnya, maka akan dikenai sanksi administratif berupa kenaikan pajak sebesar $25 \%$ dari pokok pajak yang terutang serta sanksi administrastif berupa bunga sebesar $2 \%$ (dua persen).

\section{Permasalahan Pengelolaan Tempat Parkir di Kota Malang}

Penelitian ini mencoba mengurai beberapa permasalahan yang menjadi tumpang tindih dalam pengelolaan perparkiran di Kota Malang antara pajak dan retribusi. Kewenangan Pemkot Malang dalam pengaturan pengelolaan parkir Kota Malang meliputi 1) Penetapan dan kerjasama Pengelolaan parkir, 2) Penentuan jenis-jenis tempat parkir, 3) Pengusahaan, 4) Perijinan, 5) Pemungutan, serta 6) Pembinaan dan pengawasan. Ruang lingkup dari pengelolaan tempat parkir ini mengatur mengenai beberapa lokasi tempat parkir. Akar masalah dari pengelolaan tempat parkir di Kota Malang adalah belum lengkapnya regulasi berupa Peraturan Walikota yang mengatur tata cara pemungutan berdasarkan Perda Nomor 4 Tahun 2009.

1. Teknis Penetapan Tempat-Tempat Parkir beserta prosedur pemungutannya

Prinsip pelayanan publik haruslah mengandung kejelasan untuk memberikan kepastian, baik kepada pemberi maupun penerima layanan. Selain itu, data yang digunakan juga harus akurat, sehingga diperlukan ketepatan dalam pengambilan keputusan. Keputusan yang diambil oleh Pemkot Malang akan berdampak terhadap kebijakan perparkiran yang akan dijalankan. Untuk menjalankan Perda Kota Malang Nomor 4 Tahun 2009 perlu ada Peraturan Walikota (Perwal) sebagai pegangan bagi implementator (pelaksana) di lapangan. Perwal tersebut berhubungan dengan pengelolaan perparkiran yang berisi mengenai bagaimana teknis pengelolaan parkir, seperti : penetapan tempat parkir (titik parkir). Ketika titik parkir sudah di tetapkan maka Dishub memiliki pegangan untuk menetapkan berapa potensi yang dimiliki kota Malang, sehinggga akan berpengaruh signifikan terhadap PAD Kota Malang. Setiap lokasi parkir memiliki target retribusi parkir yang harus disetorkan dengan jumlah yang berbeda sesuai potensinya. Selama ini yang terjadi adalah penentuan target retribusi berdasarkan kesepakatan antara petugas parkir dan Dishub yang mana sebelumnya dilakukan inventarisasi terlebih dahulu oleh pihak Dishub sebelum menentukan target pada setiap lokasi parkir. Setelah dipantau selama waktu yang ditentukan, maka Dishub bisa menentukan target yang harus disetorkan oleh petugas parkir pada suatu lokasi titik parkir. Bahkan, beredar informasi dari jukir bahwa adanya sertifikat lahan parkir atau surat penetapan lokasi parkir yang dibuat oleh oknum Dishub yang diperjual belikan. Fatalnya, Pemerintah Kota Malang bukan menyusun Perwal tentang pengelolaan tempat parkir, melainkan malah membuat Perda baru yang memuat kenaikan tarif retribusi parkir jasa umum. Berikut ini adalah bagan tarif parkir berdasarkan Perda Kota Malang yang mengaturnya:

Tabel 1. Perbandingan tarif Retribusi Parkir Kota Malang Berdasarakan Peraturan Daerah Kota Malang Nomor 1 Tahun 2011 tentang Retribusi Jasa Umum dan Peraturan Daerah Kota Malang Nomor 3 Tahun 2015 tentang Retribusi Jasa Umum

\begin{tabular}{|l|c|c|}
\hline \multicolumn{1}{|c|}{ JENIS KENDARAAN } & $\begin{array}{c}\text { Peraturan Daerah Kota Malang } \\
\text { Nomor 1 Tahun 2011 tentang } \\
\text { Retribusi Jasa Umum (Lama) }\end{array}$ & $\begin{array}{c}\text { Peraturan Daerah Kota Malang } \\
\text { Nomor 3 Tahun 2015 tentang } \\
\text { Retribusi Jasa Umum (Baru) }\end{array}$ \\
\hline $\begin{array}{l}\text { Truk Gandeng, Truk Trailler dan } \\
\text { bus besar }\end{array}$ & Rp. 6.000,- & Rp. 10.000,- \\
\hline Truk dan minibus dan sejenisnya & Rp. 3.000,- & Rp. 5.000,- \\
\hline $\begin{array}{l}\text { Mobil sedan, Jeep, Pick Up dan } \\
\text { sejenisnya sebesar }\end{array}$ & Rp. 1.500,- & Rp. 3.000,- \\
\hline Sepeda Motor sebesar & Rp. 700,- & Rp. 2.000,- \\
\hline
\end{tabular}

Sumber : Analisis Data Penelitian, Maret 2020 


\section{REFORMASI}

ISSN 2088-7469 (Paper) ISSN 2407-6864 (Online)

Volume 10 Nomor 1 (2020)

Di dalam Perda Nomor 3 Tahun 2015 tentang Retribusi Jasa Umum, untuk tarif tepi jalan raya atau tarif tempat parkir umum terkesan dipaksakan, karena tarif yang dinaikkan hanya untuk retribusi jasa umum dan tidak berlaku untuk tarif jasa usaha. Namun pada prakteknya yang terjadi di lapangan. Tarif retribusi parkirnya dipukul rata seperti tarif yang tertera di Perda Nomor 3 Tahun 2015 tentang Retribusi Jasa Umum. Padahal tarif retribusi jasa usaha masih menggunakan Perda Nomor 2 Tahun 2011 tentang Retribusi Jasa Usaha. Dengan munculnya Perda yang mengatur tarif parkir yang baru, Pemkot Malang berharap bisa menggenjot PAD Kota Malang. Berikut peneliti sajikan data mengenai realisasi pendapatan dari retribusi parkir dari tahun ke tahun :

Tabel 2. Target dan Realisasi Retribusi Parkir dari tahun 2011 sampai dengan tahun 2018

\begin{tabular}{|c|c|c|}
\hline TAHUN & TARGET & REALISASI \\
\hline 2011 & Rp 2.500.000.000,- & Rp 2.400.755.500,- \\
\hline 2012 & $\operatorname{Rp} 2.100 .000 .000,-$ & Rp 2.172.347.500,- \\
\hline 2013 & Rp 2.310.000.000,- & Rp 2.315.000.000,- \\
\hline 2014 & Rp 3.000.000.000,- & Rp 3.007.574.000,- \\
\hline 2015 & $\operatorname{Rp} 4.000 .000 .000,-$ & Rp 4.024.402.000,- \\
\hline 2016 & $\operatorname{Rp}$ 6.352.000.000,- & Rp 6.353.896.000,- \\
\hline 2017 & $\operatorname{Rp}$ 6.527.000.000,- & Rp 6.528.625.000,- \\
\hline 2018 & $\operatorname{Rp} 7.352 .000 .000,-$ & Rp 6.854.976.000,- \\
\hline
\end{tabular}

Sumber : Bapenda Kota Malang, Maret 2020

Dari tabel tersebut, dapat diamati bahwa meskipun tarif retribusi parkir sudah dinaikkan dari 50$185 \%$ tergantung jenis kendaraannya. Ternyata tidak bisa memberikan kontribusi yang signifikan terhadap PAD Kota Malang. Seharusnya target parkir sejak tahun 2015 (yang diberi warna kuning) juga dinaikkan 100\% minimal 8 milyar karena tarif retribusi sudah dinaikkan. Bahkan dari data tersebut, dapat kita ketahui bahwa realisasi retribusi parkir di tahun 2018 tidak memenuhi target yang ditetapkan. Padahal tarif retribusi parkir telah dinaikkan. Hal ini juga tidak jauh berbeda dengan realisasi target retribusi parkir jasa usaha. Melalui tabel berikut akan disajikan target dan realisasi retribusi tempat khusus parkir sejak tahun 2016 sampai dengan 2019. Dimana target nya masih tetap dari tahun ke tahun.

Tabel 3. Target dan Realisasi Retribusi Tempat Khusus Parkir dari tahun 2016 sampai dengan tahun 2019

\begin{tabular}{|c|c|c|}
\hline TAHUN & TARGET & REALISASI \\
\hline 2016 & $\operatorname{Rp} 648.000 .000,-$ & $\operatorname{Rp} 660.450 .000,-$ \\
\hline 2017 & $\operatorname{Rp} 648.000 .000,-$ & $\operatorname{Rp} 648.923 .000,-$ \\
\hline 2018 & $\operatorname{Rp} 648.000 .000,-$ & $\operatorname{Rp} 658.890 .000,-$ \\
\hline 2019 & $\operatorname{Rp} 648.000 .000,-$ & $\operatorname{Rp} 771.713 .000,-$ \\
\hline
\end{tabular}

Sumber : Bapenda Kota Malang, Maret 2020

Padahal, dapat kita ketahui bahwa sejak diberlakukannya Perda Nomor 3 Tahun 2015 tentang Retribusi Jasa Umum, semua tarif parkir baik jasa umum maupun jasa usaha menjadi mendadak dipukul rata. Walaupun seharusnya masih menggunakan Perda Nomor 2 Tahun 2011 tentang Retribusi Jasa Usaha. Seharusnya realisasi pendapatan dari retribusi bisa lebih banyak dari tahun sebelumnya dan terus meningkat bukan flat.

Berbeda dengan sektor pajak parkir, regulasi yang mengatur pajak parkir sudah sangat lengkap dan baik, hal ini dibuktikan dengan adanya perda dan perwal yang saling bersinergi. Sehingga pelaksanaan bisa maksimal dan potensi pajakpun bisa terlaksana dengan baik. Sehingga Bapenda bisa melakukan pendataan dan pendaftaran tempat parkir yang sekiranya berpotensi menjadi pajak parkir. Sehingga, realisasi pajak selalu memenuhi target pajak yang ditargetkan. Namun pada tahun 2019 realisasi pajak 


\section{REFORMASI}

ISSN 2088-7469 (Paper) ISSN 2407-6864 (Online)

Volume 10 Nomor 1 (2020)

parkir tidak terpenuhi, hal ini disebabkan adanya lelang kinerja Walikota Malang dimana Bapenda mendapatkan target 70 milyar untuk sektor pajak. Sehingga dibagi rata terhadap semua jenis pajak tidak terkecuali pada pajak parkir mendapatkan target sebesar Rp8,5 milyar, padahal kenaikan Wajib Pajak Parkir tidak terlalu signifikan sehingga alokasi target yabg ditetapkan terlalu besar. Seharusnya, untuk sektor parkir punya potensi yang jauh lebih besar. Berikut ini adalah tabel target dan realisasi pajak parkir dari tahun ke tahun sebagai berikut :

Tabel . 4 Realisasi Pajak Parkir dari tahun 2016 sampai dengan tahun 2018

\begin{tabular}{|c|c|c|}
\hline Tahun & Target & Realisasi \\
\hline 2016 & $3.501 .998 .000,-$ & Rp 4.894.523.130,- \\
\hline 2017 & $4.501 .998 .000,-$ & Rp 5.280.261.785,- \\
\hline 2018 & $5.500 .000 .000,-$ & Rp 5.702.455.562,- \\
\hline 2019 & $8.500 .000 .000,-$ & Rp 6.876.031.498,- \\
\hline
\end{tabular}

Sumber : Bapenda Kota Malang, Maret 2020

Ketiadaan Perwal pengelolaan parkir menyebabkan posisi regulasi untuk retribusi parkir sangat lemah. Hal ini sangat berdampak terhadap langkah - langkah di lapangan yang dilakukan oleh Dishub tidak bisa menentukan titik-titik parkir yang potensial dan tidak bisa menetapkan target retribusi parkir sesuai potensi di masing - masing titik parkir yang ada di Kota Malang. Sehingga, banyak terjadi penyimpangan di lapangan yang dilakukan oleh oknum jukir. Baik itu parkir legal (resmi) ataupun parkir yang tidak berijin (ilegal). Beberapa penyimpangan tersebut terangkum sebagai berikut :

Pertama, munculnya lahan-lahan parkir ilegal yang mendadak menjadi bisnis lahan parkir dikarenakan volume parkir kendaraan di Kota Malang yang sangat tinggi. Biasanya hal ini terjadi pada parkir tepi jalan raya, restoran, cafe, atau ATM yang ramai pengujungnya seperti di daerah Jalan Semeru, Jalan Bromo, Jalan Bandung, ATM di Jalan Ijen, ATM Bersama di UNISMA, ATM di Jl. Dieng, dan beberapa tempat lainnya. Bahkan, beberapa lahan parkirpun tak luput mengatasnamakan masyarakat dalam hal ini dilakukan oleh karang taruna, seperti lokasi parkir di beberapa alfamidi, alfamart dan indomaret, taman kunang-kunang, taman slamet, kemudian di kampung warna-warni jodipan, dan masih banyak lagi. Dari sinilah, dapat dilihat bahwa pengawasan dan ketegasan dalam melakukan tindakan terhadap lokasi-lokasi parkir yang ilegal belum optimal.

Kedua, sejak dinaikkannya tarif parkir berdasarkan Perda Nomor 3 Tahun 2015 tentang Retribusi Jasa Umum, semakin banyak bermunculan jukir-jukir liar. Jukir tersebut jarang terlihat, apalagi membantu ketika para konsumen pengguna tempat parkir mengalami kesulitan dalam memarkirkan kendaraan maupun untuk menyeberangkan kendaraan . Bahkan banyak dari mereka, langsung nongol dan meminta konsumen membayar parkir dan tanpa memberikan karcis parkir. Kejadian itu paling sering dialami ketika parkir di kawasan pertokoan. Mereka beroperasi di tempat-tempat yang sekiranya ramai pengunjung dan potensial menjadi tempat parkir, ruko-ruko yang seharusnya bebas parkir menjadi berbayar padahal itu merupakan ranah pajak parkir, warung makan kecil di pinggir jalan yang sekiranya ramai tetiba muncul jukir dadakan padahal dia adalah tukang becak yang biasanya mangkal di sekitaran tempat tersebut, lebih parah lagi yaitu beberapa ATM bersama di Kota Malang yang menjadi tempat mangkalnya para jukir ilegal. Mereka yang masuk dalam kelompok ini tidak memiliki ijin untuk melakukan penarikan tarif parkir dan hasil dari pendapatan parkir tersebut tidak diberikan kepada pemerintah, guna memberikan pemasukan untuk meningkatkan Pendapatan Asli Daerah.

Ketiga, Parkiran yang sudah legalpun dan ditandai dengan garis parkir, juga tidak mengindahkan aturan yang ada. Banyak tempat parkir yang seharusnya di gunakan untuk area mobil, tapi digunakan untuk parkir sepeda motor atau seharusnya posisi parkir ada derajat kemiringannya sesuai tanda garis parkir yang sudah dibuatkan oleh Dishub ternyata posisi parkirnya dibuat lurus, hal ini bisa kita jumpai di 


\section{REFORMASI}

ISSN 2088-7469 (Paper) ISSN 2407-6864 (Online)

Volume 10 Nomor 1 (2020)

area pecinan menuju maupun seputaran Pasar Besar Malang. Lain lagi dengan parkir tepi jalan di area Ramayana, harusnya hanya 1 saf namun karena ketika pengunjung ramayana sedang ramai, bisa jadi bukan satu saf tapi bisa menjadi 3 saf dengan memakan separuh badan jalan. Begitu juga dengan parkiran di sekitar Alun-Alun Kota Malang di depan Kantor Pos Besar Malang.

Keempat, berebut lahan parkir. Hal ini terjadi di beberapa lokasi dimana masyarakat tidak paham mengenai peraturan yang berlaku dan mengaku merasa lebih berhak karena berada di wilayahnya. Seperti contoh pengelolaan parkir di lingkungan Perkantoran Terpadu Pemkot Malang. Sejak Januari 2020, Petugas pemungut parkir dari Dishub tidak lagi melakukan pemungutan di Perkantoran Terpadu Blok A dan digantikan oleh petugas perorangan, sehingga menimbulkan gesekan dengan masyarakat yang mengatasnamakan warga kelurahan setempat dan mengaku lebih berhak untuk mengelola. Hal lain terjadi juga di salah satu daerah Indomaret Dinoyo. Parkiran Indomaret adalah lahan parkir yang memberikan fasilitas bebas parkir, namun masyarakat mengatasnamakan karang taruna meminta untuk mengelolanya, sehingga diadakan rapat mediasi sampai dengan tingkat kelurahan dan sampai saat ini belum ada kejelasannya.

Kelima, Bahkan prosedur penyetoran pemungutan retribusi parkir di Kota Malang ke Dishub masih menggunakan by person bukan melalui fasilitas perbankan. Berbeda dengan pajak yang sudah melalui sistem online. Selain itu, Juru parkir atau koordinator parkir yang seharusnya diberikan kuitansi sebagai tanda bukti penyetoran dari Dishub banyak yang tidak mendapatkan kuitansi tanda setor retribusi, melainkan hanya ditukar dengan karcis parkir saja.

\section{Pengusahaan dan Perijinan}

Ijin Usaha Parkir dibutuhkan untuk memberikan ijin terhadap orang atau badan yang akan mengusahakan usaha tempat parkir khusus atau untuk perluasan tempat khusus parkir. Tempat khusus parkir ini disebut pula Pajak Parkir yang pengelolaannya ada di Bapenda, namun pengurusan izin usahanya ada di Dishub. Sayangnya, selama ini Dishub tidak pernah bisa mengeluarkan karena belum ada Perwal yang mengaturnya. Sehingga, dalam aplikasi di lapangan untuk tempat - tempat yang seharusnya menjadi objek pajak parkir tidak bisa mengurus menjadi Wajib Pajak parkir, malah dipungut retribusi oleh Dishub. Inilah yang akhirnya menjadi tumpang tindih pengelolaan antara pajak parkir dan retribusi parkir.

Di sinilah pentingnya pemahaman mengenai definisi retribusi parkir dan pajak parkir. Baik di tataran petugas lapangan (Dishub dan Bapenda), jukir, dan masyarakat yang akan membuka usaha perparkiran, serta pengguna layanan parkir. Terkadang ada oknum yang mengambil kesempatan dari ketidaktahuan ini. Harusnya lokasi berdasarkan Perda merupakan ranah pajak malah diklaim menjadi retribusi. Tidak jarang pengusaha yang memiliki ruko ketika dipanggil oleh Bapenda untuk didaftarkan NPWPD, mereka mengatakan bahwa petugas lapangan dari Dishub sudah mendatangi mereka untuk menarik retribusi setiap bulannya.

\section{Pembinaan dan Pengawasan Pengelolaan Parkir di Kota Malang}

Berdasarkan Pasal 18 ayat 1 Perda Nomor 4 Tahun 2009 tentang Pengelolaan Tempat Parkir yang berbunyi bahwa "pembinaan dan pengawasan atas kegiatan tempat parkir umum dan/atau tempat parkir khusus dilakukan oleh Walikota atau Pejabat yang ditunjuk." Dishub adalah Organisasi Perangkat Daerah (OPD) yang bertanggung jawab melaksanakan kegiatan pengelolaan lokasi parkir mulai dari sistem perekrutan jukir, lokasi (titik-titik) parkir, pengawasan segala kegiatan parkir, hingga evaluasi kerja. Namun kinerja Dishub belum optimal, sebab faktanya di lapangan masih banyak sekali kecurangan yang dilakukan oleh petugas parkir baik yang memiliki ijin ataupun tidak memiliki ijin. Hal itu disebabkan karena minimnya pengawasan dan pembinaan yang dilakukan oleh Dinas Perhubungan. 


\section{REFORMASI}

ISSN 2088-7469 (Paper) ISSN 2407-6864 (Online)

Volume 10 Nomor 1 (2020)

Dalam aturannya, Pemkot Malang dalam mengelola tempat parkir umum dan parkir khusus yang dimiliki atau dikelola Pemkot Malang akan dibantu petugas parkir, dimana juru parkir ini diberikan surat penunjukan sebagai juru parkir pada petak atau lokasi parkir yang bersangkutan dan Kartu Tanda Pengenal Juru Parkir. Surat penunjukan dan KTP Jukir dikeluarkan oleh Kepala Dishub dan dapat diperbaharui/diperpanjang, dimana dalam melaksanakan tugasnya Jukir wajib memakai rompi terdaftar dan membawa surat penunjukan dalam melaksanakan tugasnya. Petugas Parkir yang lebih dikenal dengan Juru Parkir (Jukir) dilarang mengalihkan surat tugas tanpa seizin walikota atau pejabat yang ditunjuk dalam hal ini adalah Dishub apabila jukir mengalihkan surat penunjukan maka dengan otomatis akan dicabut, dan Jukir yang menerima pengalihan tersebut dianggap tidak sah atau surat penunjukan dapat dicabut dan juru parkir yang menerima pengalihan dianggap tidak sah atau ilegal. Tidak jauh berbeda dengan tata cara pengelolaan penentuan titik parkir, ternyata tata cara penerbitan surat penunjukan dan KT Pengenal Juru Parkir juga belum memiliki Perwal.

Naiknya tarif parkir di Kota Malang menyebabkan semakin maraknya jukir liar yang tidak dibekali dengan Kartu Tanda Petugas Parkir, surat penunjukan, dan rompi petugas parkir. Banyak dari mereka yang tiba-tiba hadir ketika masyarakat hendak meninggalkan lokasi tempat mereka memarkir sepedanya. Lebih miris lagi, ketika banyak dari jukir liar tersebut menggunakan rompi jukir ilegal dikarenakan rompi jukir yang digunakan tidak ada identitas di rompinya. Rompi resmi yang berasal dari dishub selain ada nama jukir juga disertai nomer jukir yang terdaftar di Dishub. Hal ini terjadi karena rompi parkir mudah di dapatkan baik secara offline di Pasar Comboran atau secara online di beberapa market place dengan harga yang sangat terjangkau. Dipatok dengan harga mulai empat puluh lima ribu rupiah hingga delapan puluh ribu rupiah, profesi juru parkir "ilegal" sudah bisa dilakukan. Berikut peneliti sertakan bukti screen capture market place yang menjual rompi parkir khas milik Jukir di Kota Malang :

Gambar 4 Penjualan Rompi Parkir dengan Harga Terjangkau di Market Place

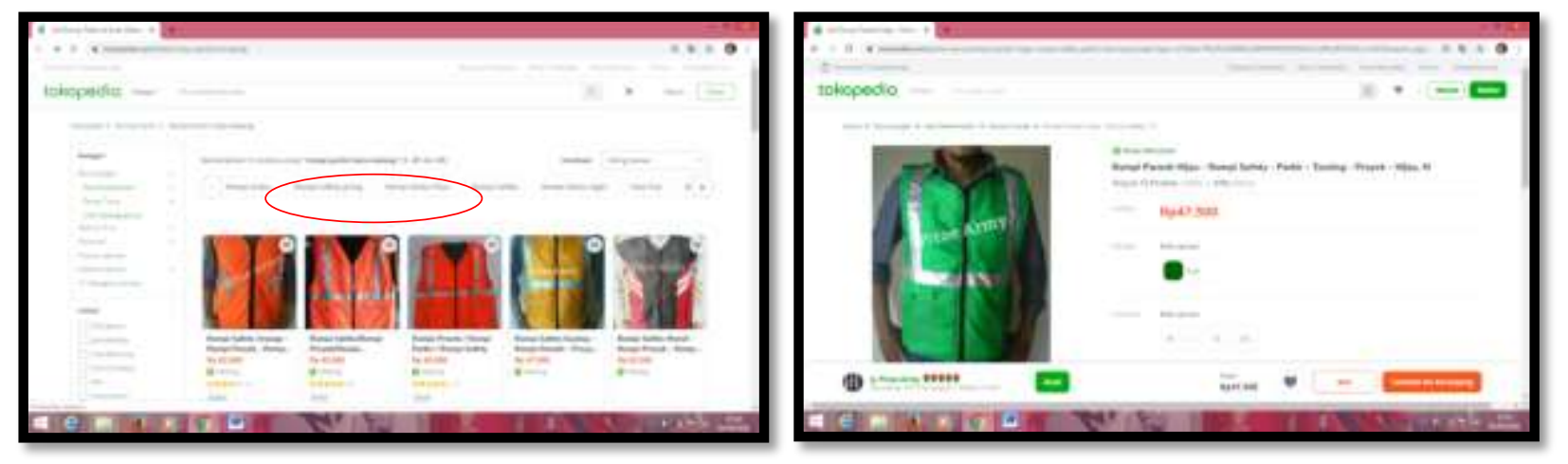

Sumber: www.tokopedia.com (2020)

Pelanggaran semacam ini merupakan pemandangan lumrah yang terjadi di Kota Malang, hal ini disebabkan rendahnya pengawasan dari Dishub. Selain itu personil yang dimiliki Dishub untuk melakukan pengawasan di lokasi parkir juga sangat minim. Jika pembiaran seperti ini terus berlanjut, maka akan sangat merugikan Pemkot Malang sendiri. Banyak jukir liar yang memungut parkir kepada masyarakat tanpa melakukan setoran terhadap Dishub, belum lagi mereka yang memungut di area rukoruko yang harusnya menjadi ranah Pajak Parkir, belum lagi beberapa tempat yang seharusnya dilakukan pemungutan Jasa Usaha yang menjadi dipungut Jasa Umum, seperti di Pasar Burung Splendid. Seharusnya, secara aturan Pasar Hewan Splendid masuk dalam ranah retribusi jasa usaha dengan tarif retribus jenis kendaraan sepeda motor adalah seribu rupiah dikarenakan berada di bawah naungan Dinas Pasar, namun faktanya parkiran di Pasar Hewan Splendid dikelola perorangan dengan tarif dua ribu 


\section{REFORMASI}

ISSN 2088-7469 (Paper) ISSN 2407-6864 (Online)

Volume 10 Nomor 1 (2020)

rupiah. Disini tanpa perlu kita kalkulasikan secara detail, sudah terlihat kebocoran retribusi yang sangat signifikan. Berikut adalah karcis parkir di Pasar Hewan Splendid yang seharusnya retribusi jasa usaha :

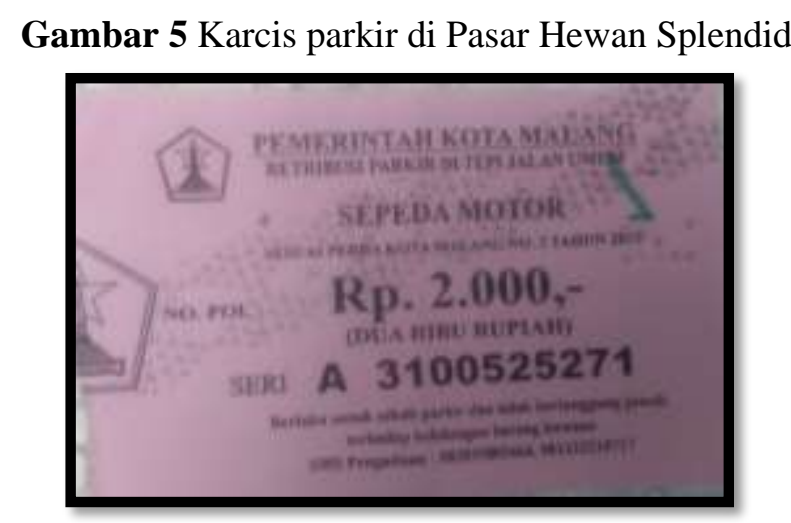

Sumber : Dokumentasi Penelitian, April 2020

Ketika karcis yang biasa diterimakan, kita perhatikan dengan seksama. Disana tertulis tentang klausal "tidak bertanggung jawab terhadap kehilangan barang bawaan" hal ini bertentangan denga tujuan pengelolaan perparkiran yang ada di Perda Nomor 4 Tahun 2009 pasal 3 poin (d) bahwa Pengaturan Pengelolaan Tempat Parkir bertujuan untuk memberikan perlindungan kepada masyarakat yang memarkir kendaraannya terhadap bahaya, kerugian dari tindak kejahatan ditempat parkir yang telah ditentukan. Hal ini juga diperkuat di pasal 19 bahwa jukir bertugas untuk menjaga keamanan dan ketertiban setiap kendaraan. Dengan begitu semakin jelas bahwa jukir harus bertanggung jawab atas segala keamanan kendaraan yang di parkir, baik barang yang ada di kendaraan maupun kendaraannya. Karena jika lalai maka jukir wajib mengganti rugi dan bisa di tuntut hukuman pidana. Dengan kasus tersebut, kesannya Dishub melindungi jukir bukan malah melindungi konsumen pengguna jasa parkir. Seharusnya sebagai pengawas dan pembina pengelolaan parkir, Dishub tidak mencetak karcis parkir dengan klausal yang bertentangan dengan esensi yang ada di Perda Nomor 4 Tahun 2009 tentang Pengelolaan Tempat Parkir.

Jika dihubungkan dengan teori prinsip pelayanan publik, ada prinsip keamanan, masyarakat dalam hal ini konsumen parkir harus merasakan rasa aman dan kepastian hukum. Bagaimana konsumen pengguna parkir bisa merasa aman jika antara aturan dan pelaksanaan di lapangan tidak singkron. Prinsip kenyamanan, selain mengandung keamanan juga perlu kenyamanan, dimana jukir melayani dengan ramah, memberikan hak karcis parkir terhadap konsumen. Prinsip lainnya dalam manajemen pelayanan adalah tanggung jawab. Bertanggung jawab terhadap pelayanan disini adalah jukir yang bertugas harus totalitas dalam bekerja, serta bertanggungjawab terhadap segala masalah yang timbul di lokasi parkir yang dijaga oleh jukir tersebut.

\section{PENUTUP}

Berdasarkan hasil dan pembahasan diatas dapat disimpulkan bahwa pengelolaan tempat parkir di Kota Malang terbagi menjadi Retribusi Parkir (retribusi parkir jasa umum dan retribusi parkir jasa usaha) dikelola oleh Dishub dan Pajak Parkir dikelola oleh Bapenda. Selain itu adanya Perda ganda yang mengatur tarif retribusi parkir jasa umum dan retribusi parkir jasa usaha yang menjadikan hal ini adalah ranah rawan kebocoran, karena keduanya memiliki tarif yang berbeda namun penarikan terhadap masyarakat dipersamankan. Akar permasalahan pengelolaan tempat parkir di Kota Malang adalah belum tersusunnya perwal tentang pengelolaan tempat parkir sehingga 1) Dishub tidak bisa menentukan titik parkir dan menentukan potensi target rertibusi. Inilah yang menyebabkan 2) munculnya jukir ilegal di setiap sudut kota. Selain itu, 3) izin usaha perparkiran untuk Tempat Khusus Parkir dipegang oleh Dishub, padahal Tempat Khusus Parkir adalah ranah Pajak, sehingga sering terjadi tumpang tindih 


\section{REFORMASI}

ISSN 2088-7469 (Paper) ISSN 2407-6864 (Online)

Volume 10 Nomor 1 (2020)

pengelolaan mana yang seharusnya menjadi ranah pajak parkir dan retribusi parkir, disinilah peran kepala daerah untuk mensinkronkan peran Dishub dan peran Bapenda. Minimnya pengawasan dan pembinaan juga menjadi salah satu alasan penyebab jukir legal tidak melakukan tugasnya dengan baik.

\section{DAFTAR PUSTAKA}

Chasanah, Isnatul. (2019). Kronik Persoalan Parkir di Kota Malang: Wacana BUMD, Parkir Elektronik, Hingga Premanisme Parkir Liar. Malang : https://www.satukanal.com/kronik-persoalan-parkir-dikota-malang-wacana-bumd-parkir-elektronik-hingga-premanisme-parkir-liar/ diakses 28 Maret 2020

Haezer, Eben Panca (2019) Jukir yang Tarik Tarif Parkir Rp50 Ribu di Malang Mengaku Setor ke Dishub. Ini Tanggapan Dishub https://surabaya.tribunnews.com/2019/06/17/jukir-yang-tarik-tarifparkir-rp50-ribu-di-malang-mengaku-setor-ke-dishub-ini-tanggapan-dishub?page $=2$ diakses 2 April 2020

Malangtimes. 2015. Karcis Salah Cetak, Pemilik Kendaraan Bingung. diakses Maret 2020 dari: https://www.malangtimes.com/baca/6959/20151129/111433/karcis-salah-cetak-pemilik-

kendaraan-bingung

Mukarom, Zaenal and Wijaya, Muhibudin (2015). Manajemen Pelayanan Publik. Bandung : CV Pustaka Setia

Mukarom, Zaenal and Wijaya, Muhibudin (2018) Membangun Kinerja Pelayanan Publik. Bandung: CV Pustaka Setia

Peraturan Daerah Kota Malang Nomor 3 Tahun 2015 tentang Retribusi Jasa Umum

Peraturan Daerah Kota Malang Nomor 1 Tahun 2011 tentang Retribusi Jasa Umum

Peraturan Daerah Kota Malang Nomor 16 tahun 2010 tentang Pajak

Peraturan Daerah Kota Malang Nomor 2 Tahun 2011 tentang Retribusi Jasa Usaha

Peraturan Daerah Kota Malang Nomor 4 Tahun 2009 tentang Pengelolaan Tempat Parkir

Peraturan Daerah Kota Malang Nomor 8 tahun 2019 tentang Perubahan Kedua atas Peraturan Daerah Kota Malang Nomor 16 tahun 2010 tentang Pajak Daerah

Rohman, Abd and Trihardianto, Willy Tri (2019) Reformasi Birokrasi dan Good Governance. In: Reformasi Birokrasi dan Good Governance. Malang : Intrans Publishing

Rohman, Abd. (2018). Dasar-Dasar Manajemen Publik. Malang : Intrans Publishing

Satukanal.com. 2019. Kronik Persoalan Parkir di Kota Malang: Wacana BUMD, Parkir Elektronik, Hingga Premanisme Parkir Liar. Diakses 28/3/2020 dari: https://www.satukanal.com/kronikpersoalan-parkir-di-kota-malang-wacana-bumd-parkir-elektronik-hingga-premanisme-parkir-liar/ Sugiyono. (2018). Metode Penelitian Kombinasi (Mixed Scanning). Bandung : Alfabeta

Tokopedia.com. 2020. Diakses 1 April 2020 jam 15.05 dari: https://www.tokopedia.com/find/rompiparkir/c/malang

Tokopedia.com. 2020. Diakses 1 April 2020 jam 15.05 dari: https://www.tokopedia.com/pitoearmy/rompi-parasit-hijau-rompi-safety-parkir-touring-proyek-hijaum?trkid=f\%3DCa0000L248P0W0S0Sh\%2CCo0Po0Fr0Cb0_src\%3Dsearch_page\%3D1_ob\%3D1 000_q\%3Drompi+parkir_bmexp\%3D0_po\%3D9_catid\%3D4226_bmexp\%3D0\&whid=2422737

Tribunnews.com. 2019. Ini Juru Parkir yang Tarik 50 Ribu untuk Bus di Alun-alun Kota Malang, Sekarang di Kantor Polisi. diakses 2/4/2020: https://surabaya.tribunnews.com/2019/06/17/jukiryang-tarik-tarif-parkir-rp50-ribu-di-malang-mengaku-setor-ke-dishub-ini-tanggapandishub?page $=2$

Undang-Undang nomor 28 tahun 2009 tentang Pajak Daerah dan Retribusi.

Undang-Undang Pemerintahan Daerah, 2015. Bandung : Fokusindo Mandiri 